\title{
Comparison of Readiness for Telecommunication of Thailand and other Countries in AEC
}

\section{Thunyawadee Sucharidtham*}

Department of Applied Economics, College of Agriculture and Natural Resources, National Chung Hsing University, Taiwan

\begin{abstract}
This study had the objectives of analyzing the causes, strengths and weaknesses of infrastructure related to Thailand's telecommunications compared with those of other countries in AEC. Data was derived from the rankings of different agencies outside the country, namely the ICT Development Index, Digital Economy Rankings, Network Readiness and World Competitiveness Yearbook. The study results showed that for Thailand to get ready in terms of policy and investment budget, it might need cooperation from other AEC member countries that scored high in preparation of readiness standards in telecommunications such as Singapore, Malaysia and Brunei in order to promote Thailand's telecommunications to become a leader among the countries in AEC when Thailand joins the ASEAN Economic Community in 2015.
\end{abstract}

Keywords: Telecommunications; Digital economy rankings; Economic Community

\section{Introduction}

This study focused on analyzing Thailand's readiness in telecommunications dealings in comparison with other AEC countries, which are Cambodia, Myanmar, The Philippines, Brunei, Malaysia, Laos, Vietnam, Singapore and Indonesia, with the objectives of defining the important factors from the results of the comparison of the readiness rankings of the infrastructure as well as analyzing the relevant causes and finding out the weaknesses and the strengths of Thailand's telecommunications structure.

The study provided additional information on various factors for making decisions, setting goals and planning for the readiness of Thailand's telecommunications dealings. The data can be used for telecommunications cooperation among AEC members and for becoming a leader in telecommunications at the approach of AEC in 2015.

Beginning from readiness ranking and ICT assessment the study continued investigating the rankings of many agencies outside Thailand in their ranking of readiness of infrastructure using the ICT Development Index, Digital economy Rankings, Readiness for the Networked World Guide, Networked Readiness Index, World Competitiveness Yearbook, and Telecommunication Standards or the International Telecommunications Union [1-3].

From examining the six indicators, only four were found to be appropriate. These were ICT Development Index, Digital economy Rankings, Networked Readiness Index and World Competitiveness Yearbook [4]. Therefore, this study used only these four indicators since their data was more up-to-date, complete, clear and adequate for comparison and analysis to find weaknesses and strengths for decision making, goal setting and readiness preparation planning of Thailand's telecommunications dealings to cope with the advent of the ASEAN Economic Community in 2015.

\section{Data}

\section{ICT development index}

The ICT Development Index is the ranking of readiness in ITC. Consideration is given to such factors as technology, economy and society consisting of 9 variables divided into 3 major types, each type having a different scoring population. These are:

- $\quad$ Access dealing with members using basic telephones, mobile telephones, home computers and the Internet.

- Usage dealing with users of personal Internet, Broadband Internet and Broadband mobile phones.

- $\quad$ Skills dealing with the ratio of educated members and rate of literacy.

\section{Digital economy rankings}

Digital economy Rankings is readiness ranking of ICT by considering technology, economic and social factors, with 39 variables divided into 6 main types each with different total scores. These are:

- Infrastructure for connecting the technology dealing with the number of Internet Broadband users, the quality of the Broadband Internet, monthly membership fees for users of Broadband Internet, the number of mobile phone users, the quality of mobile phones, the number of Internet users, the quality of the International Bandwidth and the safety of Internet use.

- The business environment dealing with the political and the macro-economic environment, including market opportunities, promotion policies for private entrepreneurs, promotion policies for investment from overseas, the foreign trade system and exchange rate, tax system, capital recruitment and labor market.

- Social and cultural environment dealing with education level,

*Corresponding author: Thunyawadee Sucharidtham, College of Agriculture and Natural Resources, Department of Applied Economics, National Chung Hsing University, Taiwan, Tel: +66-53-94-22-07; E-mail: thunyawadee@gmail.com

Received June 15, 2015; Accepted October 16, 2015; Published October 23 2015

Citation: Sucharidtham T (2015) Comparison of Readiness for Telecommunication of Thailand and other Countries in AEC. J Glob Econ 3: 158. doi:10.4172/23754389.1000158

Copyright: (c) 2015 Sucharidtham T. This is an open-access article distributed under the terms of the Creative Commons Attribution License, which permits unrestricted use, distribution, and reproduction in any medium, provided the original author and source are credited. 
Internet literacy, level of entrepreneurs, the skills of the manpower, and the level of innovation.

- The legal environment dealing with the efficiency of the legal system in general, laws related to the Internet, degree of censoring printed matters and news prior to its distribution, convenience in registration of new businesses and electronic citizen ID cards.

- Government policy and vision dealing with the government expenses in ICT and the ratio of the Gross National Product, strategy in digital development, electronic government strategy as well as the quantity of electronics.

- ICT usage adaptation between the consumers and business sector dealing with ICT expenses per capita and the level of electronics business development, the level of online commerce, the customers' Internet usage, and online public service use as well as online service use by the business sector.

\section{Networked readiness index}

Networked Readiness Index (NRI) is the ranking to assess the readiness and competence in the usage and benefits gained from ICT which consists of 10 variables classified into 4 main types as follows:

- Environment: market and innovation, politics and rules and regulations.

- Readiness: infrastructure, service fees and income as well as skills.

- Usage: by individuals, the business sector and the government.

- Impact: economic and social impacts.

\section{World competitiveness yearbook}

The World Competitiveness Yearbook is the ranking of competence in Technological Infrastructure which consists of 20 variables divided into 4 main types as follows:

- Economic situations dealing with national economy, international trade, international investment, labor hiring and prices.

- Government efficiency dealing with finance, financial policies, institutional framework, business law and the social framework.

- Business efficiency dealing with production efficiency, the labor market, finance, operation management, attitudes and values.

- Infrastructure dealing with general infrastructure, technological infrastructure, including science, health, environmental and educational infrastructure.

\section{Results and Discussion}

\section{ICT Development Index}

ICT Development Index is a kind of readiness ranking of ICT initiated by the International Telecommunication Union based on 3 main types or criteria: access, usage and skills. The analysis of this part started from looking at the overall picture of the ICT Development Index and individual criteria before analyzing the strengths and weaknesses of Thailand by comparing it with nine other countries in AEC.

Overall picture of the ICT development index: From Table 1, it was found that Thailand was ranked $5^{\text {th }}$ among the nine countries of AEC. Since the Index did not give the overall picture of the ranking of Myanmar, only nine countries had adequate data for this. Since Thailand was ranked $5^{\text {th }}$, it was impossible to identify the strengths and weakness in the overall picture. However, when compared at a global level, Thailand was ranked at 89 whereas Singapore was ranked at $19^{\text {th }}$ or 70 levels above Thailand, and within AEC, Singapore was ranked first. At a global level, Thailand had scores at 3.30 out of 10 . The index revealed that Thailand needs to develop a lot more for readiness to enable it to compete in telecommunications when it enters AEC.

The strengths according to ICT development index: The ICT Development Index showed that Thailand had only one strength out of three, which was in terms of skills, resulting from such variables as the ratio of education and literacy rate of the adults. In terms of strength in skills, Thailand was ranked number one with a score of 7.18 among eight of the other countries in the AEC and it was ranked number 69 at the global level (Table 1). This showed that Thailand was quite strong in education, which is an important strength as the education and literacy rate become part of the basic readiness of all countries to enter competition in telecommunications with AEC and is the first thing that should be improved. Human resource development received a higher investment than materials development. Investment in human resource development includes time, a clear policy and money. But investment in material needs just money. Moreover, education is considered a basis for all aspects of development, in particular readiness development for Thailand to compete in telecommunications.

\begin{tabular}{|c|c|c|c|c|c|c|c|c|c|c|c|c|}
\hline \multirow[b]{2}{*}{ Country } & \multicolumn{3}{|c|}{ Overall picture Index } & \multicolumn{3}{|c|}{ Access } & \multicolumn{3}{|c|}{ Usage } & \multicolumn{3}{|c|}{ Skills } \\
\hline & $\begin{array}{c}\text { Rank in } \\
\text { AEC }\end{array}$ & $\begin{array}{c}\text { World rank } \\
(152)\end{array}$ & Score & $\begin{array}{c}\text { Rank in } \\
\text { AEC }\end{array}$ & $\begin{array}{c}\text { World rank } \\
(152)\end{array}$ & Score & $\begin{array}{c}\text { Rank in } \\
\text { AEC }\end{array}$ & $\begin{array}{c}\text { World rank } \\
(152)\end{array}$ & Score & $\begin{array}{c}\text { Rank in } \\
\text { AEC }\end{array}$ & $\begin{array}{c}\text { World rank } \\
\text { (152) }\end{array}$ & Score \\
\hline Singapore & 1 & 19 & 7.08 & 1 & 11 & 8.14 & 1 & 15 & 6.03 & 2 & 73 & 7.08 \\
\hline Brunei & 2 & 43 & 5.61 & 2 & 37 & 6.51 & 2 & 39 & 4.01 & 3 & 75 & 7.01 \\
\hline Malaysia & 3 & 58 & 4.45 & 3 & 65 & 4.70 & 3 & 50 & 3.15 & 5 & 92 & 6.57 \\
\hline Vietnam & 4 & 81 & 3.53 & 4 & 72 & 4.39 & 4 & 76 & 1.57 & 7 & 108 & 5.74 \\
\hline Thailand & 5 & 89 & 3.30 & 5 & 89 & 3.62 & 6 & 93 & 1.05 & 1 & 69 & 7.18 \\
\hline $\begin{array}{l}\text { The } \\
\text { Philippines }\end{array}$ & 6 & 92 & 3.22 & 6 & 101 & 3.14 & 5 & 83 & 1.49 & 4 & 83 & 6.83 \\
\hline Indonesia & 7 & 101 & 2.83 & 7 & 102 & 3.13 & 7 & 105 & 0.69 & 6 & 94 & 6.50 \\
\hline Cambodia & 8 & 117 & 1.99 & 8 & 112 & 2.45 & 8 & 123 & 0.35 & 9 & 120 & 4.34 \\
\hline Laos & 9 & 121 & 1.90 & 9 & 123 & 2.21 & 9 & 130 & 0.26 & 8 & 117 & 4.56 \\
\hline Myanmar & $\mathrm{N} / \mathrm{A}$ & $\mathrm{N} / \mathrm{A}$ & $\mathrm{N} / \mathrm{A}$ & $\mathrm{N} / \mathrm{A}$ & $\mathrm{N} / \mathrm{A}$ & N/A & $\mathrm{N} / \mathrm{A}$ & $\mathrm{N} / \mathrm{A}$ & $\mathrm{N} / \mathrm{A}$ & $\mathrm{N} / \mathrm{A}$ & $\mathrm{N} / \mathrm{A}$ & $\mathrm{N} / \mathrm{A}$ \\
\hline
\end{tabular}

Source: International Telecommunication Union 2011 
As stated above, Thailand's strength in skills was ranked first in AEC and was four levels above Singapore at the world level since Singapore was in the $73^{\text {rd }}$ rank (Table 1). Therefore, Thailand should maintain the strength in skills and continue developing in this aspect to be more distinctive than at present.

The weaknesses according to the ICT development index: According to the ICT Development Index Thailand was found to have two weaknesses out of three, which were:

Access: This was assessed from the numbers of clients having basic telephones and those with mobile phones as well as the number of households having computers and access to the Internet.

Usage: This was assessed from the private Internet users, members of Broadband Internet and users of Broadband mobile phones.

The ration of 2 out of a total of 3 in weakness means that Thailand will have to greatly improve the development of readiness in the infrastructure of telecommunications. From Table 1 for access readiness, Thailand ranked 5th among eight of the AEC countries (no data from Myanmar was available). Although Thailand was in the middle among its AEC counterparts, it received scores of only 3.62 out of 10 and it was 4.52 points less than Singapore which came in number one in AEC. That is, Singapore was 2.24 times higher than Thailand. Thus if Thailand wants to be a leader in telecommunications in AEC, it needs to have a policy plan for investment in infrastructure to allow its people more access to the infrastructure in telecommunications. This can be achieved by increasing the number of basic telephones and mobile telephones as well as the number of households that have access to the Internet.

As for the weakness in usage according to Table 1, Thailand was ranked $6^{\text {th }}$ among the eight countries of AEC (no data from Myanmar). Thailand received only 1.05 points out of 10 or 4.98 points less than Singapore, which was ranked number one. This means Singapore was 5.74 times higher than Thailand. This is a serious weakness for Thailand and it needs to develop a great deal, especially in investment in $3 \mathrm{G}$ to increase the number of private Internet users, Broadband Internet members and Broadband mobile telephones to upgrade the rank in readiness for infrastructure of Thailand's telecommunications when the country enters AEC. The research team agreed that the government should have an urgent and clear policy concerning this to increase Thailand's potential.

From the discussion above, it can be seen that although the ICT Development Index indicated that Thailand had 2 weaknesses out of a total of 3, its strength for being number one in skill development among AEC members can be a good and important point because for skills development, the ratio of educated people and the rate of literacy of adults usually takes time and a huge budget. In this light, it could be said that Thailand's policy on education has been on the right track, be it the free 12 years' compulsory education or the loan fund for education (Table 1).

Thailand had two types of weakness: access assessed from the number of members with basic telephones and mobile phones, households that had computers and the Internet and usage measured from the number of private Internet users, Broadband Internet members and Broadband mobile telephone users. Based on the variable used for assessment, the government should set a clear policy and continuation in infrastructure as these received very low scores. Thus, Thailand has to accelerate the development with a clear policy and more capital to catch up with when entering into AEC by 2015.

\section{Digital economy rankings}

Digital economy Rankings is the ICT ranking from The Economist Intelligence Unit Limited which looks at 6 major factors: the infrastructure of linkage and technology, the business environment, the social and cultural environment as well as the legal environment, including the vision of the government and lastly the adaptation of ICT for their own use among the consumers and the business. The research team conducted an analysis of the overall weaknesses and strengths by factor to compare them with those of AEC.

Overall picture of the digital economy rankings: From Table 2, it was found that the overall picture of the Digital Economy Rankings for Thailand was number 3 out of 6 AEC countries since the data for Brunei, Cambodia, Laos and Myanmar was absent. Although Thailand was in the middle rank, its score was only 4.86 out of ten. When compared with that of Singapore, which was the first rank, the score was 3.36 point from Thailand and 1.69 times that of Thailand.

Therefore, it can be said that Thailand needs to improve its readiness in infrastructure a great deal. And even though its strength was number 3, the outcome of the score comparison with Singapore shows that Thailand was far behind the leading country and this is considered Thailand's weakness. More details can be obtained from the analysis of this aspect later.

Strengths according to the digital economy rankings: Out of 6 factors, two were found to be Thailand's strengths as follows:

- Business environment factors which had 9 variables, namely political and macro-economic factors, market opportunity, private entrepreneurs promotion policy, foreign investment promotion policy, overseas trade system and exchange rate, tax system, capital recruitment and lastly, labor market.

- Legal environment factors which had 5 variables, namely efficiency of the legal system in general, internet laws, level of the review or censorship of printed news before dissemination, convenience of new business registration and lastly, electronic citizen identity cards.

From Table 2, it was found that Thailand's score in business environment factors was as high as 6.83 and the variable analysis in this aspect showed that the variables were related to policy. Therefore, it could be considered that business environment factors required policy and supportive measures from the government and it would take a long time if Thailand wanted to be an AEC leader in infrastructure for telecommunications and it should maintain and continually improve those variables.

The factors considered to be Thailand's strengths were the legal environment factors. As shown in Table 2, the score 6.35 of Thailand is quite high as it is only 2.35 away from that of Singapore where Singapore is ranked number eight in the world or one of the world's top ten. Therefore, if the government continues improving the laws to render benefit for readiness in infrastructure for telecommunications in Thailand, it will be easier to become a leader in this area.

Weaknesses according to the digital economy rankings: There are 4 out of 6 factors that were considered Thailand's weaknesses that the government should consider in order to make Thailand the leader in telecommunications infrastructure among the AEC as follows:

- Infrastructure on linkage and technology which had 8 variables, namely the number of Broadband Internet users, its quality, its membership, monthly income, the number of mobile phone users, 


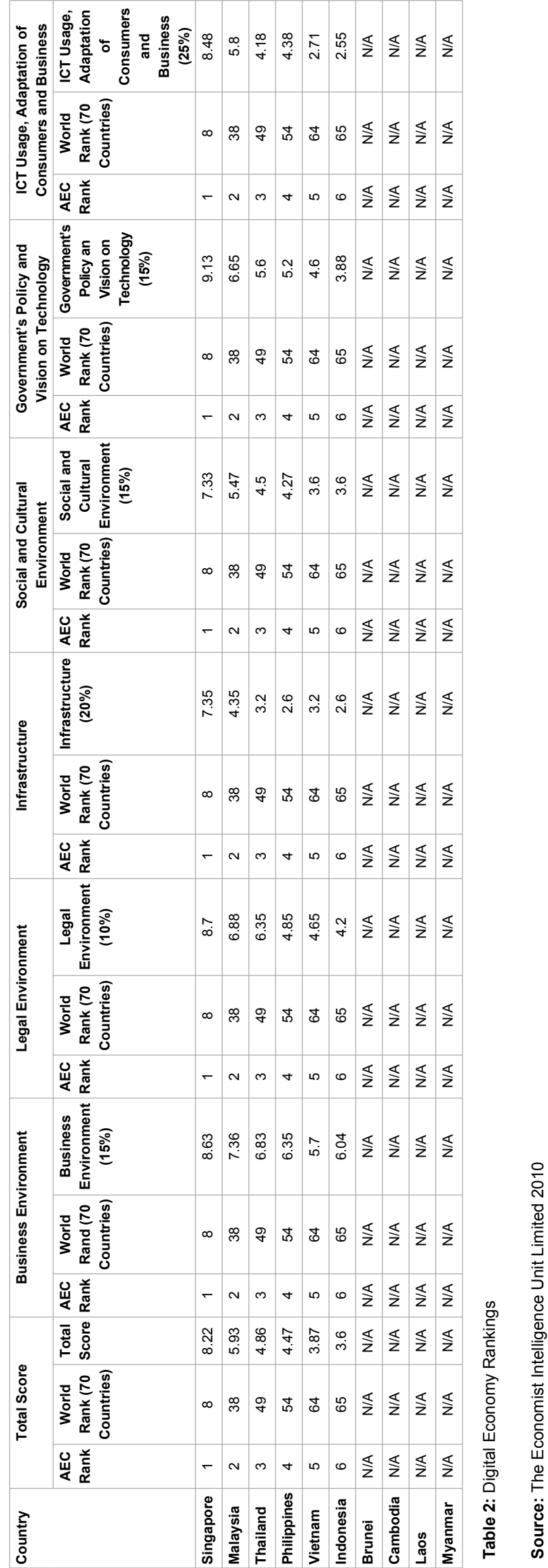


its quality, the number of Internet users, the amount of international Internet bandwidth and lastly, the security of Internet usage.

- The social and cultural environment which had five variables, namely education, Internet literacy, levels of entrepreneurs, manpower skills and innovation.

- The government's policy and vision concerning technology which had 6 variables, namely the ration of the government's ICT expenses and the GDP, digital development strategies, electronic government, online services for the general public and business as well as the quantity of electronics.

- $\quad$ ICT usage adaptation among the consumers and business which had 6 variables, namely ICT expenses per capita, level of development of the electronics industry, the level of online commerce, the consumers' Internet usage and public online usage as well as online service usage of the business sector.

From the four factors above, the research team could identify Thailand's weaknesses in infrastructure on linkage and technology for which Thailand received only 3.2 points, which was 4.15 points away from Singapore whose score was 2.29 times more than Thailand's (Table 2). This factor had such variables as Broadband Internet users, its quality, its monthly membership income, the number of Internet users, the amount of bandwidth Internet and lastly security of Internet usage. These were internationally significant variables that Thailand could not overlook in order to be ready for improvement of infrastructure for telecommunications and to be the leader in AEC in this area. It is urgent to improve these variables to be more advanced than it is now.

Table 2 shows the ranking of the social and cultural environment which the research team found to be a factor for the weaknesses in improving the infrastructure of Thailand's telecommunications. Thailand received only 4.5 points which was 2.83 points apart from that of Singapore or 1.62 less than Singapore. The variables that were used as indicators in this factor were the level of education, Internet literacy and entrepreneurship as well as manpower skills along with the level of innovation. These variables were very significant for the improvement of Thailand's telecommunications infrastructure. Therefore, it is necessary for the government to establish measures and policies that correspond to these variables.

Regarding the factors on the government's policies and vision on technology, the research team viewed it as Thailand's weakness because it is the starting point for management plans for readiness in Thailand's telecommunications infrastructure. The variables used as indicators in this factor were the ratio of the government's expenses on ITC and the GDP, the digital development strategies, the electronic government strategies, online purchases and hiring, online public service for people and business and the quality of the electronics. Thailand scored only 5.60 for these factors, 3.53 points apart from that of Singapore or 1.63 times less than Singapore (Table 2). Therefore, the scores should be increased to prove that Thailand is ready to be the leader in telecommunications when AEC is materialized.

Table 2 shows the factor on the consumers' and business adaptation of ICT usage that is also considered a weakness in the Digital Economy Rankings. This factor had the variables that were used as indicators such as the consumers' per capita expenses on ICT, levels of electronic business development, levels of online commerce, consumers' Internet usage, consumers' public online service usage and online service usage of the business sector. Thailand had a score of 4.38 which was 4.10 apart from Singapore, which was ranked first in AEC, or 1.9 times more than Thailand. This was so because Thailand's readiness in telecommunications infrastructure was rather low. Improvement in this area should result in a higher adaptation on ICT usage on the part of the consumers and the business sector.

\section{Networked Readiness Index}

The Networked Readiness Index (NRI) is an indicator of ICT which involves 4 basic factors: environment, readiness, usage and impacts.

The overall picture of the networked readiness index: Table 3 shows the overall picture of the NRI which reveals that Thailand was ranked number 4 out of 8 AEC country members (Laos and Myanmar were not applicable). Even though Thailand was in the middle range, in the global rank it was number 77 . Thailand's score was 3.78 while Singapore, which was ranked number one in the AEC and number 2 in the world, had a score of 5.86 or 1.35 times higher than that of Thailand. Moreover, Indonesia was number 5 in AEC and number 80 in the world (only 3 ranks behind Thailand) and had a score of 3.75 , only 0.03 points less than Thailand. The ranking according to the NRI indicated that Thailand needs to increase its readiness in telecommunications infrastructure as its being in the fourth rank means very little in terms of score when compared with the one in the fifth rank.

Strengths according to the networked readiness index: Regarding the strengths according to the Networked Readiness Index that the research team found was of 2 factors. Even though in the overall

\begin{tabular}{|c|c|c|c|c|c|c|c|c|c|c|c|c|}
\hline \multirow[t]{3}{*}{ Country } & \multicolumn{3}{|c|}{ Overall Picture } & \multicolumn{4}{|c|}{ Environment } & \multicolumn{5}{|c|}{ Readiness } \\
\hline & \multirow{2}{*}{$\begin{array}{l}\text { Rank in } \\
\text { AEC }\end{array}$} & \multirow{2}{*}{$\begin{array}{c}\text { World Rank } \\
\text { (142 countries) }\end{array}$} & \multirow[t]{2}{*}{ Score } & \multirow{2}{*}{$\begin{array}{l}\text { Rank in } \\
\text { AEC }\end{array}$} & \multirow{2}{*}{\begin{tabular}{|c|} 
World \\
Rank \\
$(142$ \\
countries $)$
\end{tabular}} & \multicolumn{2}{|c|}{ Environment } & \multirow{2}{*}{$\begin{array}{c}\text { Rank in } \\
\text { AEC }\end{array}$} & \multirow{2}{*}{$\begin{array}{c}\text { World Rank } \\
(142 \\
\text { countries) }\end{array}$} & \multicolumn{3}{|c|}{ Readiness } \\
\hline & & & & & & $\begin{array}{l}\text { Political and } \\
\text { Rules and } \\
\text { Regulations }\end{array}$ & $\begin{array}{l}\text { Market and } \\
\text { Innovation }\end{array}$ & & & Infrastructure & $\begin{array}{l}\text { Monthly } \\
\text { Service } \\
\text { Charge }\end{array}$ & Score \\
\hline Singapore & 1 & 2 & 5.86 & 1 & 2 & $5.96(1)$ & $5.51(1)$ & 1 & 2 & $5.88(20)$ & $5.84(29)$ & $6.46(2)$ \\
\hline Malaysia & 2 & 29 & 4.8 & 2 & 29 & $4.87(24)$ & $4.97(24)$ & 2 & 29 & $4.12(65)$ & $5.69(41)$ & $5.29(47)$ \\
\hline Thailand & 3 & 54 & 4.04 & 3 & 54 & $4.03(48)$ & $3.95(76)$ & 3 & 54 & $4.66(48)$ & $2.58(135)$ & $5.78(25)$ \\
\hline Philippines & 4 & 77 & 3.78 & 4 & 77 & $3.67(69)$ & $4.24(54)$ & 4 & 77 & $3.06(107)$ & $5.80(33)$ & $4.87(74)$ \\
\hline Vietnam & 5 & 80 & 3.75 & 5 & 80 & $3.48(88)$ & $4.09(64)$ & 5 & 80 & $3.11(103)$ & $5.78(34)$ & $4.99(69)$ \\
\hline Indonesia & 6 & 83 & 3.7 & 6 & 83 & $3.55(79)$ & $3.62(109)$ & 6 & 83 & $3.12(101)$ & $5.07(76)$ & $4.89(73)$ \\
\hline Brunei & 7 & 86 & 3.64 & 7 & 86 & $3.15(107)$ & $3.69(107)$ & 7 & 86 & $3.66(80)$ & $5.18(72)$ & $4.86(77)$ \\
\hline Cambodia & 8 & 108 & 3.32 & 8 & 108 & $3.64(73)$ & $3.69(106)$ & 8 & 108 & $4.07(66)$ & $3.34(110)$ & $3.82(111)$ \\
\hline Laos & $\mathrm{N} / \mathrm{A}$ & N/A & $\mathrm{N} / \mathrm{A}$ & $\mathrm{N} / \mathrm{A}$ & N/A & $\mathrm{N} / \mathrm{A}$ & $\mathrm{N} / \mathrm{A}$ & $\mathrm{N} / \mathrm{A}$ & N/A & $\mathrm{N} / \mathrm{A}$ & N/A & N/A \\
\hline Myanmar & N/A & N/A & N/A & $\mathrm{N} / \mathrm{A}$ & N/A & N/A & N/A & $\mathrm{N} / \mathrm{A}$ & $\mathrm{N} / \mathrm{A}$ & $\mathrm{N} / \mathrm{A}$ & N/A & N/A \\
\hline
\end{tabular}

Source: Networked Readiness Index 2012 
picture Thailand was ranked number 4 in AEC and number 77 in the world, analysis of the individual variables in terms of the political environment showed that Thailand was ranked number 68 or 19 ranks below Indonesia which had the $5^{\text {th }}$ rank in AEC. In terms of market and innovation environment, Thailand was in the $54^{\text {th }}$ rank (4.24 points higher than Brunei which was ranked number 3 in AEC and number 76 in the world or 22 ranks below Thailand (Table 3). Therefore, Thailand should maintain its scores in the market and innovation environment and improve the variable in the political environment to become the leader in telecommunications in AEC.

As for the readiness factor which had 3 variables: infrastructure, monthly service income and skills, it was found that the monthly service charge or income was a strong point for Thailand as the overall score was 5.80 or only 0.04 points less than Singapore which ranked number one in AEC and Thailand was ranked number 33 in the world while Singapore was number 29 (Table 3 ). This means that when AEC approached with competition in telecommunications, Thailand will surely be able to compete in terms of price.

Weaknesses according to the networked readiness index: As for the weaknesses from the ranking according to the Networked Readiness Index, the researcher found 2 main factors concerning usage which had two variables that were ranked rather low in the world ranking. One was the private usage which had only 2.73 points and which was lower than that of Singapore, the top ranked in the AEC, by 2.12 times. Thailand's world rank was 92 out of 142 . At the same time, the variable related to the government's usage was only 3.61 points with a rank of $86^{\text {th }}$ in the world (Table 4). Therefore, to be the leader in infrastructure for telecommunications in AEC, Thailand needs to urgently develop these two variables.

Table 4 Shows the impacts of the two variables were economic and social impacts. The former had a score of 2.93 points, 2.09 times less than Singapore and the latter had 3.64 points, 1.62 times less than Singapore. This indicated that the Thai government and the relevant agencies should pay attention to the two impacts, in particular the economic one, in order to prepare Thailand in infrastructure for telecommunications and to become the leader in this area in AEC.

\section{World competitiveness yearbook}

This is the indicator of the World Competitiveness Yearbook with 4 main factors in which Thailand was ranked number 5 of 9 AEC countries (Myanmar is not applicable) with only 3.30 points, 2.14 times less than Singapore (Table 5). Therefore, the Thai Government and the relevant agencies need to pay more attention to it.

From the four indicators, The ICT Development Index, The Digital economy Rankings, The Networked Readiness Index and The World Competitiveness Yearbook, Thailand's rank was in the middle of all of the indicators. The analysis of each factor showed that when compared with other countries in the ASEAN Economic Community, Thailand had both weaknesses and strengths and the weaknesses were higher than the strengths by just one variable. This indicated that it needs to improve all six major factors related to the indicators as follows:

- Access with 3 variables: Basic telephone members, mobile phone members, households with computers and households with Internet access.

- Usage with 3 variables: Private internet users, Broadband Internet members and Broadband mobile phones.

- $\quad$ Social and Cultural environment with 5 variables: Education level, Internet literacy level, entrepreneurs level, manpower skills and innovation level.

- Government policy and vision in Technology with 6 variables: ratio of government's ICT expenses and GDP, digital development strategy, electronic government and quality of electronics.

- Adaptation of consumers' and business sector usage of ICT with 6 variables: Consumers' ICT expenses per capita, level of electronic business development, level of online commerce, consumers' usage, consumers' online public service usage and the business sectors' online service usage.

- Impact with 2 variables: Economic and social impacts.

Regarding the strengths, there are 5 factors that Thailand needs to maintain as follows:

- $\quad$ Skills with 2 variables: Ratio of educated population and the number of literate adults.

- Business environment factor with 9 variables: Political and macroeconomic environment, market opportunity, private entrepreneur promotion policy, foreign investment promotion policy, overseas trade system and exchange rate, tax system, capital recruitment and labor market.

- Legal environment factor with 5 variables: The efficiency of

\begin{tabular}{|c|c|c|c|c|c|c|c|c|c|}
\hline \multirow[t]{3}{*}{ Countries } & \multicolumn{5}{|c|}{ Usage } & \multicolumn{4}{|c|}{ Impact } \\
\hline & \multirow[t]{2}{*}{ Rank in AEC } & \multirow{2}{*}{$\begin{array}{l}\text { World Rank } \\
\text { (142ประเทศ) }\end{array}$} & \multicolumn{3}{|c|}{ Usage } & \multirow{2}{*}{$\begin{array}{c}\text { Rank in AEC } \\
\text { Economic }\end{array}$} & \multirow{2}{*}{$\begin{array}{c}\text { World Rank } \\
\text { (142ประเทศ) } \\
\text { Social }\end{array}$} & \multicolumn{2}{|c|}{ Impact } \\
\hline & & & Private Usage & $\begin{array}{c}\text { Business } \\
\text { Usage }\end{array}$ & $\begin{array}{c}\text { Government } \\
\text { Usage }\end{array}$ & & & Economic & Social \\
\hline Singapore & 1 & 2 & $5.79(10)$ & $5.25(14)$ & $5.78(2)$ & 1 & 2 & $6.14(2)$ & $5.91(3)$ \\
\hline Malaysia & 2 & 29 & $4.01(47)$ & $4.43(27)$ & $5.35(6)$ & 2 & 29 & $3.97(31)$ & $5.31(15)$ \\
\hline Thailand & 3 & 54 & $4.57(39)$ & $3.61(61)$ & $4.12(50)$ & 3 & 54 & $3.28(64)$ & $4.18(46)$ \\
\hline Philippines & 4 & 77 & $2.73(90)$ & $3.63(60)$ & $3.61(86)$ & 4 & 77 & $2.93(96)$ & $3.64(71)$ \\
\hline Vietnam & 5 & 80 & 2.39 (103) & $3.76(49)$ & $3.70(75)$ & 5 & 80 & $2.84(106$ & $3.72(66)$ \\
\hline Indonesia & 6 & 83 & $2.94(80)$ & $3.48(78)$ & $4.14(48)$ & 6 & 83 & $2.85(102)$ & $3.81(61)$ \\
\hline Brunei & 7 & 86 & $2.61(95)$ & $3.58(63)$ & $3.66(79)$ & 7 & 86 & $3.16(77)$ & $3.42(88)$ \\
\hline Cambodia & 8 & 108 & $1.82(126)$ & $3.37(89)$ & $3.57(88)$ & 8 & 108 & $2.52(126)$ & $3.36(93)$ \\
\hline Laos & $\mathrm{N} / \mathrm{A}$ & $\mathrm{N} / \mathrm{A}$ & N/A & $\mathrm{N} / \mathrm{A}$ & $\mathrm{N} / \mathrm{A}$ & N/A & N/A & N/A & $\mathrm{N} / \mathrm{A}$ \\
\hline Myanmar & $\mathrm{N} / \mathrm{A}$ & $\mathrm{N} / \mathrm{A}$ & $\mathrm{N} / \mathrm{A}$ & $\mathrm{N} / \mathrm{A}$ & $\mathrm{N} / \mathrm{A}$ & $\mathrm{N} / \mathrm{A}$ & $\mathrm{N} / \mathrm{A}$ & $\mathrm{N} / \mathrm{A}$ & $\mathrm{N} / \mathrm{A}$ \\
\hline
\end{tabular}

Source: Networked Readiness Index 2012 
Citation: Sucharidtham T (2015) Comparison of Readiness for Telecommunication of Thailand and other Countries in AEC. J Glob Econ 3: 158. doi:10.4172/2375-4389.1000158

Page 7 of 8

\begin{tabular}{|l|c|c|}
\hline \multirow{2}{*}{ Countries } & \multicolumn{2}{|c|}{ The Overall Picture of the Index } \\
\cline { 2 - 3 } & Rank in AEC & Score \\
\hline Singapore & 1 & 7.08 \\
\hline Thailansia & 2 & 5.61 \\
\hline Philippines & 3 & 4.45 \\
\hline Vietnam & 4 & 3.53 \\
\hline Indonesia & 5 & 3.30 \\
\hline Brunei & 6 & 3.22 \\
\hline Cambodia & 7 & 2.83 \\
\hline Laos & 8 & 1.99 \\
\hline Myanmar & 9 & 1.90 \\
\hline Source: N/A & N/A \\
\hline
\end{tabular}

Source: World Competitiveness Yearbook 2012

Table 5: The Overall Picture of the Ranking by the World Competitiveness Yearbook.

legal the system in general, Internet laws, legal censorship of printed materials and news before distribution, convenience in new business registration and electronic citizen ID card.

- $\quad$ Environment with 2 variables: Market and innovation.

- $\quad$ Readiness with 3 variables: Infrastructure, monthly service fees and skills.

It can be said that, from the five factors of its strengths Thailand should maintain, it can be considered fortunate that the strengths take some time to develop such as the ratio of educated people and literate adults. As for the weaknesses, it needs to improve the policy and increase budget on investment, which means the people concerned need to urgently prepare the policy to provide readiness in telecommunications for Thailand.

In preparing the readiness on policy and investment budget Thailand might have to seek cooperation from countries that scored high in preparing readiness standards on telecommunications like Singapore, Malaysia and Brunei when the AEC is inaugurated. This will enable Thailand to be the leader and handle telecommunications in ASEAN by 2015.

\section{Conclusion and Recommendations}

The ranking of telecommunications indicators could be summed up in a table to show the strengths and weaknesses from various factors involved as follows:

Table 6 Shows that the factors that give Thailand the strengths in readiness in telecommunications when compared with other countries in AEC involves 5 variables together which are skills, business, environment, legal environment, general environment and readiness. The strengths are advantageous to Thailand and should give the government some guidelines for effective planning and policy along with good management to enhance the strengths more.

As for skills, this strength should give Thailand the best opportunity because to gain a high score in this respect takes quite a long time and high amount of investment, especially in terms of educational development. The weaknesses or a low score in this respect could cause a lot of problems. To raise the literacy rate takes time besides capital like other kinds of development.

As for readiness, which is another important strong point for Thailand when entering AEC, especially in terms of the monthly service income where Thailand was ranked number two next to Singapore.

Therefore, when AEC actually begins, Thailand may not have to adjust much in order to compete in price for telecommunications in AEC.

As for strength in environment, the factors measured were general

\begin{tabular}{|c|c|c|}
\hline Number & Factors & Variables \\
\hline \multirow[t]{2}{*}{1} & \multirow[t]{2}{*}{ Skills } & Ratio of educated population \\
\hline & & Rate of literacy \\
\hline \multirow[t]{9}{*}{2} & \multirow[t]{9}{*}{ Business Environment } & Political environment \\
\hline & & Macroeconomic environment \\
\hline & & Marketing opportunities \\
\hline & & Policy to promote private entrepreneurs \\
\hline & & Policy to promote investment from overseas \\
\hline & & Foreign trade system and exchange rate \\
\hline & & Tax system \\
\hline & & Capital recruitment \\
\hline & & Labor market \\
\hline \multirow[t]{5}{*}{3} & \multirow[t]{5}{*}{ Legal Environment } & Effectiveness of legal system in general \\
\hline & & Internet laws \\
\hline & & $\begin{array}{l}\text { Level of censorship on printed materials and } \\
\text { news before distribution }\end{array}$ \\
\hline & & Convenience of business registration \\
\hline & & Electronic citizen ID \\
\hline \multirow[t]{2}{*}{4} & \multirow[t]{2}{*}{ General Environment } & Market innovation environment \\
\hline & & Political environment and regulations \\
\hline \multirow[t]{3}{*}{5} & \multirow[t]{3}{*}{ Readiness } & Infrastructure \\
\hline & & Monthly service charge \\
\hline & & Skills \\
\hline
\end{tabular}

Table 6: Strengths in Thailand's Readiness for Telecommunications in Comparison with other Countries in AEC.

\begin{tabular}{|c|c|c|}
\hline Number & Factor & Variables \\
\hline \multirow[t]{4}{*}{1} & \multirow[t]{4}{*}{ Access } & Members with basic telephones. \\
\hline & & Members with mobile telephones \\
\hline & & Households with computers \\
\hline & & Households with Internet access \\
\hline \multirow[t]{3}{*}{2} & \multirow[t]{3}{*}{ Usage } & Private Internet users \\
\hline & & Users of Broadband Internet \\
\hline & & Users of Broadband mobile telephones \\
\hline \multirow[t]{5}{*}{3} & \multirow{5}{*}{$\begin{array}{l}\text { Social and cultural } \\
\text { environment }\end{array}$} & Level of education \\
\hline & & Level of Internet literacy \\
\hline & & Level of entrepreneurship \\
\hline & & Skills of manpower \\
\hline & & Level of innovation \\
\hline \multirow[t]{6}{*}{4} & \multirow{6}{*}{$\begin{array}{l}\text { Government's } \\
\text { policy and vision on } \\
\text { technology }\end{array}$} & $\begin{array}{l}\text { The government's expenses or ICT and } \\
\text { ratio of GDP }\end{array}$ \\
\hline & & Digital development strategy \\
\hline & & Electronic government \\
\hline & & Online purchasing and hiring \\
\hline & & Online public services \\
\hline & & Number of electronic devices \\
\hline \multirow[t]{6}{*}{5} & \multirow{6}{*}{$\begin{array}{l}\text { Adaptation of ICT usage } \\
\text { among consumers and } \\
\text { businesses }\end{array}$} & ICT expenses for consumers \\
\hline & & Level of electronic development \\
\hline & & Level of Online commerce \\
\hline & & Consumers' Internet usage \\
\hline & & Consumers' online public service usage \\
\hline & & $\begin{array}{l}\text { Online service usage by the business } \\
\text { sector }\end{array}$ \\
\hline \multirow[t]{2}{*}{6} & \multirow[t]{2}{*}{ Impacts } & Economic impacts \\
\hline & & Social impacts \\
\hline
\end{tabular}

Table 7: Weaknesses in Thailand's Readiness for Telecommunications in Comparison with other Countries in AEC. 
environment and innovation, especially political as well as rules and regulations. These were quite advantageous and Thailand received rather high scores, proving quite well that the rules and regulations facilitated investment in telecommunications. Therefore, this aspect could be worth the investment for multinational companies in AEC.

Table 7 shows the weakness of Thailand in readiness in telecommunications when compared to that of other AEC members. However, the 6 factors contributing to the weakness had variables that could be adjusted and improved very easily. It only needs some financial investment and effective government policy. For example, the access factor had such variable as members of the basic telephones and mobile telephones services, households with computers. In this regard, if the government had the policy to relax on tax for the suppliers who deal with the people or facilitating the people and households to easily acquire basic and mobile telephones as well as computers, the improvement in these factors could be concretely successful. It will also automatically boost the factors on usage and application of ICT among the consumers and businesses. The policy on social cultural environment as well as the government's policy and vision on technology have to be clear and supportive to technology development.
To do so, the relevant variables must be considered. These are the level of education, the level of entrepreneurship, the skills of manpower and innovation. This means the government must promote education and include in the curriculum more on knowledge and skills related to telecommunications along with those related to telecommunications entrepreneurship. Cooperation with the AEC countries with a higher score like Singapore and Malaysia must be sought.

From the discussion, it can be seen that Thailand has both strengths and weaknesses. Fortunately the latter seem to be easy to improve. It only needs a clear policy and cooperation from AEC. At the same time the strengths of Thailand give it an advantage when it has to make investment or compete with the AEC countries.

\section{References}

1. Digital economy rankings 2010 (2010) The Economist Intelligence Unit.

2. Soumitra D (2012) The Networked Readiness Index 2012: Benchmarking ICT Progress and Impacts for the Next Decade. World Economic Forum.

3. Measuring the Information Society (2012) International Telecommunication Union.

4. IMD World Competitiveness Yearbook 2015 Results (2015) IMD. 